\title{
Educational Mobility and Transnationalization
}

\section{Peidong Yang and Yi'En Cheng}

\section{INTRODUCTION}

The concept fourth industrial revolution (4IR) currently generates perhaps as much excitement as it does vagueness and ambiguity. Coined by Klaus Schwab, ${ }^{1}$ and promulgated through the highly influential World Economic Forum (WEF) he founded, 4IR appears to be the next big idea about world technological and economic development. According to Schwab, the 4IR is 'building on the Third, the digital revolution that has been occurring since the middle of the last century. It is characterized by a fusion of technologies that is blurring the lines between the physical,

${ }^{1}$ Klaus Schwab, The Fourth Industrial Revolution (New York: Crown Publishing Group, 2017).

P. Yang $(\bowtie)$

National Institute of Education, Nanyang Technological University,

Singapore, Singapore

e-mail: Peidong.yang@nie.edu.sg

Y. Cheng

Yale-NUS College, Singapore, Singapore

(C) The Author(s) 2018

N. W. Gleason (ed.), Higher Education in the Era of the Fourth Industrial

Revolution, https://doi.org/10.1007/978-981-13-0194-0_3 
digital, and biological spheres. ${ }^{2}$ Despite its being built on the third industrial revolution (3IR), Schwab maintains that the 4IR is not merely an extension or prolongation of its predecessor, but is a distinct phase distinguished by the extraordinary velocity, scope, and system impacts of its technological advancements. In more concrete terms, Schwab identifies artificial intelligence (AI), robotics, the internet of things (IoT), autonomous vehicles, 3D-printing, nanotechnology, biotechnology as some of the key technological drivers of the 4IR; in addition, he also highlights disruptive impacts of emerging business models such as 'sharing' or 'on demand' economy (with perhaps the most iconic examples being AirBnB and Uber). ${ }^{3}$

It is argued that this burgeoning 4IR will have far-reaching and profound consequences for all actors in today's globalized world: businesses, governments, and people. ${ }^{4}$ However, what exactly these consequences will be remains unclear and essentially a matter of speculation. Considerations of the changing nature of employment and skills are often prominent within existing discussions about 4IR. If one takes a functionalist view that education primarily serves to equip members of society with the right qualities and skills to function in the prevailing socio-economic conditions, ${ }^{5}$ then such considerations can also be regarded as implicitly about education and training. For example, when writing about the opportunities and challenges associated with 4IR, Schwab asserts that talent will represent the critical factor of production, leading to a job market increasingly segregated into 'high-skill/high-pay' and 'low-skill/low-pay' segments, with the middle hollowed out. Implicitly, then, education and training in the 4IR-shaped future should aim to develop in learners high-level, high value-adding skills. ${ }^{6}$ A similar narrative is found in the Asia Pacific Economic Cooperation (APEC) Education Strategy Action Plan, which endorses multilateral cross-border collaboration between universities

\footnotetext{
${ }^{2}$ Klaus Schwab, "The Fourth Industrial Revolution: what it means, how to respond," January 14, 2016, https://www.weforum.org/agenda/2016/01/the-fourth-industrialrevolution-what-it-means-and-how-to-respond/.

${ }^{3}$ Schwab, The Fourth Industrial Revolution.

${ }^{4}$ Schwab, "The Fourth Industrial Revolution."

${ }^{5}$ Randall Collins, "Functional and Conflict Theories of Educational Stratification," American Sociological Review, 36, no. 6 (1971): 1002-1019.

${ }^{6}$ Schwab, "The Fourth Industrial Revolution."
} 
within the region, so as to deliver skills required to produce graduates who can navigate the $4 \mathrm{IR}{ }^{7}$

In this chapter, we are interested in the relationships between (higher) education, mobility, and the 4IR. We question whether and to what extent higher education (HE) has been transformed by 4IR. Furthermore, we consider whether these transformations are contributing to changing structures around educational inequality and social justice or reproducing them. We engage with these questions by drawing on our respective research on HE mobility and transnationalization in the context of Asia. We view education from a critical and loosely speaking culturalist perspective. By critical we mean that in our work we maintain a critical distance from, and a skepticism of, certain hegemonic discourses and imaginaries about education and educated persons. Instead, we pay attention to relations, practices and subjectivities of power, domination, inequality, and injustice manifested in specific educational contexts. By a culturalist perspective we mean that we treat education as a socio-cultural domain that cannot be adequately understood without being sensitive to the local social and cultural contexts to certain educational projects or configurations and attending to the cultural and subjective dimensions in educational experiences in terms of meaning-making, narratives, values, desires, and aspirations.

We adopt such a critical and broadly speaking culturalist perspective as opposed to a functionalist one not only because the former is integral to our empirical research, but also for two additional reasons. First, as evidenced in existing 4IR literature about education and training, a functionalist perspective tends to result in a kind of futurologist discussion that comprises half speculation and half prescription, both divorced from empirical observations from the ground. Secondly, our research has led us to view educational systems and configurations (such as international mobility and transnationalization) as outcomes of enduring power relations that act and interact on multiple scales: global, national, institutional, community, and individual. Because of this complex socio-cultural constitution of educational phenomena, we are somewhat skeptical of any straightforward idea about HE being transformed as a result of the alleged onset of the 4IR, especially with respect to education's role in social and cultural reproduction. Instead, with our studies depicting significant recent

\footnotetext{
${ }^{7}$ Yojana Sharma, "Universities can help overcome economic nationalism," November 23, 2017, http://www.universityworldnews.com/article.php?story=20171123200015564.
} 
trends in $\mathrm{HE}$ in the Asian context, we aim to shed light on the various social forces, interests, and contextual factors shaping HE in the first two decades of the twenty-first century. Our basic assertion is that such an understanding will continue to be valid for the near future, and thus provide a solid ground for pondering the new changes 4IR may bring to HE.

In the remaining sections, we discuss two contemporary educational phenomena that are undergoing profound intensification, namely international student mobility (ISM) and emergence of transnational higher education (TNHE) industry in the context of Asia. We then illustrate both phenomena through two cases. The first case consists of a recent form of intra-Asia student mobility involving Indian youths heading to China for English-medium Bachelor of Medicine and Bachelor of Surgery (MBBS) degrees. The second case concerns transnational education programs offered by private institutes in the city-state of Singapore. In the chapter's concluding section, we sum up the main insights emerging from our two cases, and offer these as the basis for an alternative and more critical direction for understanding the complex relationships between 4IR and HE.

\section{Educational Changes in a Contemporary Asian Context: International Mobility and Transnational Higher EDUCATION}

\section{International Student Mobility}

In tandem with the intensification of globalization, ISM in HE has undergone significant expansions over the past decades. The number of students enrolled in tertiary education outside their countries of citizenship grew from 1.3 million in $1990^{8}$ to an estimated 5 million in $2014 .{ }^{9}$ With the world now poised to enter the 4IR era, ISM is set to continue to grow: it has been projected that by 2025 there will be 8 million $\mathrm{HE}$ international students in the world. Importantly, while so far ISM has predominantly

\footnotetext{
${ }^{8}$ OECD, "Education Indicators in Focus - 2013/05 (July)," 2013, http://www.oecd. org/edu/skills-beyond-school/EDIF\%202013--N\%C2\%B014\%20\%28eng\%29-Final.pdf.

${ }^{9}$ ICEF Monitor, "The state of international student mobility in 2015," November 5 , 2015, http://monitor.icef.com/2015/11/the-state-of-international-student-mobilityin-2015/.
} 
involved student flows from Asia to the Anglophone West, ${ }^{10}$ the rise in student mobilities within Asia has caught scholarly attention more recently. ${ }^{11}$ According to UNESCO, in 2016 the East Asia and Pacific region already hosted $19 \%$ of the world's international students, trailing only behind North America and Western Europe. ${ }^{12}$ The case of Indian youths being attracted to earn their MBBS degrees in China provides an interesting lens for examining this rising trend of intra-Asia student mobility.

As a multifaceted phenomenon, ISM has been approached from various theoretical perspectives in literature. ${ }^{13}$ One of the most analytically productive ways to understand ISM is through a Bourdieusian lens focused on different forms of capital ${ }^{14}$ and their mutual conversion as a mechanism of class re/production. ISM is analyzed as a way of accumulating cultural capital which is subsequently reconverted into employability, status, social networks to facilitate the reproduction of class advantage. ${ }^{15}$ Johanna Waters's work on Hong Kong students saliently highlights how

${ }^{10}$ UNESCO, "The International Mobility of Students in Asia and the Pacific," 2013, http://unesdoc.unesco.org/images/0022/002262/226219E.pdf.

${ }^{11}$ Sheng-Ju Chan, "Shifting Patterns of Student Mobility in Asia," Higher Education Policy 25, no 0.2 (2012): 207-224; Francis L. Collins, "Regional Pathways: Transnational Imaginaries, Infrastructures and Implications of Student Mobility within Asia," Asian and Pacific Migration Journal 22, no. 4 (2013): 475-500; Christopher Ziguras and Grant McBurnie, "International Student Mobility in the Asia-Pacific: From Globalization to Regional Integration?," in Higher Education in the Asia-Pacific, ed. Simon Marginson, Sarjit Kaur, and Erlenawati Sawir (Netherlands: Springer, 2011), 123-140.

${ }^{12}$ UNESCO, "Global Flow of Tertiary-Level Students," 2016, http://www.uis.unesco. org/Education/Pages/international-student-flow-viz.aspx (site discontinued).

${ }^{13}$ Russell King et al., "Reproducing advantage: the perspective of English school leavers on studying abroad," Globalisation, Societies and Education 9, no. 2 (2011): 161-181.

${ }^{14}$ Pierre Bourdieu, "The Forms of Capital," in Handbook of Theory and Research for the Sociology of Education, ed. John G. Richardson (London: Greenwood Press, 1986), 241-260.

${ }^{15}$ Vladimír Baláž and Allan M. Williams, "Been there, done that': international student migration and human capital transfers from the UK to Slovakia," Population, Space and Place 10, no. 3 (2004): 217-237; Allan M. Findlay et al., "World class? An investigation of globalisation, difference and international student mobility," Transactions of the Institute of British Geographers, 37, no. 1 (2012): 118-131; Russell King and Enric Ruiz-Gelices, "International student migration and the European 'Year Abroad': effects on European identity and subsequent migration behavior," International Journal of Population Geography 9, no. 3 (2003): 229-252; Johanna Waters, "Geographies of cultural capital: education, international migration and family strategies between Hong Kong and Canada," Transactions Institute of British Geographers 31, no. 2 (2006): 179-192; Johanna Waters, Education, Migration, and Cultural Capital in the Chinese Diaspora: Transnational Students between Hong Kong and Canada (New York: Cambria Press, 2008). 
cultural capital is accrued transnationally, sometimes by students who are otherwise excluded from first-choice local universities in their home country/territory. ${ }^{16}$ In this sense, studying abroad also functions as a 'second chance ${ }^{17}$ strategy for certain student populations in highly competitive educational systems - a point that resonates with the case of transnational education (see below).

It is worth noting that although there has been an implicit assumption that internationally mobile students tend to be privileged socioeconomically, ${ }^{18}$ increasing evidence shows this is not necessarily the case. ${ }^{19}$ For youths from not-so-privileged backgrounds, studying abroad could be:

1. a way to bypass local barriers to education-financial and/or academic — and to get a 'second chance' at realizing their aspiration for social mobility through training in certain professions that are believed to promise such;

2. a step toward immigration to a more desirable country or place that promises higher wages and/or a greater sense of international mobility. ${ }^{20}$

Thus, pursuing educational mobility is seldom about education/learning per se, but is often deeply embedded in specific social contexts and motivated by socio-culturally shaped desires and imaginaries.

\footnotetext{
${ }^{16}$ Waters, Education, Migration, and Cultural Capital in the Chinese Diaspora.

${ }^{17}$ Rachel Brooks and Johanna Waters, "A Second Chance at 'Success': UK Students and Global Circuits of Higher Education,” Sociology 43, no. 6 (2009): 1085-1102.

${ }^{18}$ Johanna Waters, "Geographies of International Education: Mobilities and the Reproduction of Social (Dis)advantage," Geography Compass 6, no. 3 (2012): 123-136.

${ }^{19}$ Michiel Baas, Imagined Mobility: Migration and Transnationalism among Indian Students in Australia (New York: Anthem Press, 2010); Vanessa L. Fong, Paradise Redefined: Transnational Chinese Students and the Quest for Flexible Citizenship in the Developed World (Stanford: Stanford University Press, 2011); Peidong Yang, "Compromise and complicity in international student mobility: the ethnographic case of Indian medical students at a Chinese university," Discourse: Studies in the Cultural Politics of Education, online first (2018): 1-15.

${ }^{20}$ Baas, Imagined Mobility; Shanthi Robertson, Transnational Student-Migrants and the State: The Education-Migration Nexus (London: Palgrave Macmillan, 2013).
} 


\section{Transnational Higher Education}

The contemporary TNHE sector represents a case of global higher educational landscape undergoing systematic changes stemming from technological multiplication and digitization. It reveals the rapidly shifting ways in which new educational arrangements are built, delinked, reassembled, and experimented with by multiple state and non-state actors. Since the early 1990s, cross-border movements of educational programs and institutions, physically and virtually, have become one of the major transnational flows integral to the internationalization of $\mathrm{HE}^{21}$ In addition to intensified cross-border collaborations and partnerships between public and national universities, we also witness an increasing growth of private and non-state sectors venturing into HE provision, thereby contributing to the proliferation of education institutions leading to various foreign degrees and academic credentials. These can take the form of franchised overseas academic programs (including online and distance learning) or degrees, branch campuses, or private institutions modeled after overseas academic models.

In reviewing extant literature on TNHE, there is no fixed definition that scholars and education practitioners can agree on. According to UNESCO, transnational education is broadly defined as education in which the learners are located in a country different from that where the awarding institution is based. ${ }^{22}$ But in the context of China, Fang observes that 'an education provision is considered transnational when substantial investment from both foreign and Chinese sides are involved even if the provision does not award foreign degrees. ${ }^{23}$ Tim Mazzarol, Geoffery Soutar, and Michael Seng define TNHE through three overlapping waves of cross-border flows: the first 'involved students travelling to a host nation to study'; the second wave involved the 'alliance or coalition' through twinning programs; and the third wave involved 'the creation of branch campuses in foreign markets and the development of

\footnotetext{
${ }^{21}$ Futao Huang, "Internationalization of higher education in the developing and emerging countries: A focus on transnational higher education in Asia," Journal of Studies in International Education 11, no. 3-4 (2007): 421-432.

${ }^{22}$ UNESCO-CEPES, Code of Good Practice in the Provision of Transnational Education (Bucharest: UNESCO/Council of Europe, 2000).

${ }^{23}$ Fang Wenhong, "The development of transnational higher education in China: A comparative study of research universities and teaching universities," Journal of Studies in International Education 16, no. 1 (2012): 6.
} 
"on-line" delivery of courses through information and communications technologies (ICT). ${ }^{24}$ This expansive understanding of TNHE as assembled through a network of human, policy, and institutional connections across disparate places is reflected in Huang's definition that takes TNHE as "any cross-border or inter-regional higher education activities or services in a broad sense." 25

Although proponents have likened the growing TNHE sector to borderless education ${ }^{26}$ and borderless university, ${ }^{27}$ others remain wary of such straightforwardly optimistic views. Altbach, for instance, expressed concern that transnational education will deepen inequalities among the global education landscape, whereby the role of world-class universities in Western countries will be strengthened on the one hand, while other ostensibly 'second-tier' universities will continue to have little competitive potential in the globalizing world. ${ }^{28}$ Huang's assessment of case studies of TNHE across East and Southeast Asia also revealed the manner in which internationalizing strategies adopted by governments largely maintain an attitude of 'catching up' with the English-speaking world. ${ }^{29}$ In her study on Saudi Arabia and Kazakhstan, geographer Natalie Koch argues that the contemporary circulation of Western (European and North American) educational models throughout Asia contributes to shaping a global knowledge economy that largely privileges Western knowledge practices. ${ }^{30}$

The speed and scale at which ICTs are being applied to HE is also believed to have democratized learning through the flexibilization of institutional and curricular structures as well as the widening of participation.

\footnotetext{
${ }^{24}$ Mazzarol, Soutar, and Seng, "The third wave: Future trends in international education," The International Journal of Education Management 17, no. 3 (2003): 90.

${ }^{25} \mathrm{Huang}$, "Internationalization of higher education in the developing and emerging countries," 422.

${ }^{26}$ Stuart Cunningham et al., The Business of Borderless Education (Canberra: DETYA, $2000)$.

${ }^{27}$ Kevin Robins and Frank Webster, The Virtual University? Knowledge, Markets, and Management (Oxford: Oxford University Press, 2002).

${ }^{28}$ Philip G. Altbach, "Higher Education and the WTO: Globalization Run Amok," International Higher Education 23, (2001): 2-4.

${ }^{29}$ Le-Ha Phan, Transnational Education Crossing 'Asia' and 'the West': Adjusted desire, transformative mediocrity and neo-colonial disguise (London: Routledge, 2017); Huang, "Internationalization of higher education in the developing and emerging countries."

${ }^{30}$ Koch, "The shifting geopolitics of higher education: inter/nationalizing elite universities in Kazakhstan, Saudi Arabia and beyond," Geoforum 56, (2014): 46-54.
} 
The virtual university, which describes the electronic and online delivering of educational services and activities, is claimed to be the future of HE. ${ }^{31}$ One such area that has been heralded as a remedy to educational disparities is the rise of Massive Open Online Courses (MOOCs) such as Coursera, EdX, and Udemy across the 2000s. The president of EdX, Anant Agarwal, goes to the extent to claim that they 'are democratizing and reimagining education by fulfilling [their] nonprofit mission to increase access to high-quality education for everyone, everywhere. ${ }^{32}$ However, evidence gathered has shown that global information flows manifested in the digital divide are highly uneven, including barriers found in individuals' technological capacity and literacy as well as those segmented across class, gender, and race. Schwab correctly noted that inequality is the largest concern associated with the 4IR, especially when innovation and creativity tied to the techno-sciences have tended to benefit the rich while hollowing out opportunities for the poor. ${ }^{33}$ Similarly, digital technologies in (transnational) HE may potentially serve the interest of the elite more so than actually closing socio-economic gaps. To this end, Yang accurately cautions that "virtual space is infinite, but it does not promise universality or equality." 34

\section{Case 1: Indian Students on English-Medium MBBS Courses in China}

\section{The Case: Indian Doctors Made in China}

With China being the world's largest sending country of international students, its rising profile as a destination for ISM has been largely neglected so far. As of 2016, more than 440,000 foreign students studied in China. ${ }^{35}$ Although over half of these foreign students are on non-degree

${ }^{31}$ Parker Rossman, The Emerging Worldwide Electronic University: Information Age and Higher Education (Westport: Greenwood Press, 1992).

${ }^{32}$ Anant Agarwal, "MOOCs and the Global Democratization of Higher Education," June 24, 2016, https://evolllution.com/attracting-students/accessibility/moocs-and-the-globaldemocratization-of-higher-education/.

${ }^{33}$ Schwab, The Fourth Industrial Revolution.

${ }^{34}$ Yang, Rui, "Globalisation and higher education development: a critical analysis," International Review of Education, 49 no. 3-4 (2003): 281.

${ }^{35}$ PRC State Council, "More Chinese students return from overseas in 2016," March 1, 2017, http://english.gov.cn/state_council/ministries/2017/03/01/content_281475581664446. htm. 
courses, since early 2000s mainland Chinese universities have also offered programs catered to foreign students seeking full degree credentials. ${ }^{36}$ Among these were English-medium MBBS programs that target specifically international students from developing countries. The number of places on these English-medium MBBS courses increased steadily from 2095 offered by 24 universities in the 2007 admission year to the high watermark of 6020 places offered by 52 institutions in 2013, after which there was a notable decline. ${ }^{37}$ In the 2016/2017 admission (the most recent with data available), 45 Chinese institutions offered a total of 3470 places. ${ }^{38}$ Students from India most likely make up the largest singlenationality group in these MBBS programs. According to Pallivi Aiyar, Indian students first started heading to China for MBBS in their 'hundreds' since as early as $2004 / 2005 .{ }^{39}$ By 2015 , the majority of the 16,694 Indian students in China could be safely assumed to be studying MBBS. ${ }^{40}$

How has this seemingly unlikely project of intra-Asia student mobility come about? Not unlike elsewhere, in India an education in professional fields such as medicine, law, and engineering is integral to many middleclass families' social aspiration and strategy. However, medical education remains highly difficult to access in India, with affordable governmentsubsidized medical school places reserved for only the most academically competitive students. A significant for-profit private medical education sector has developed in response, ${ }^{41}$ but this sector is characterized by very expensive tuition fees. As a result, young doctor-aspirants hailing from the 'the lowest or more struggling sections of India's new middle classes' 42

${ }^{36}$ Chiharu Kuroda, "The New Sphere of International Student Education in Chinese Higher Education: A Focus on English-Medium Degree Programs," Journal of Studies in International Education 18, no. 5 (2014): 445-462.

${ }^{37}$ Medical Council of India, "List of China Colleges," 2015, http://www.mciindia.org/ MediaRoom/ListofChinaColleges.aspx (site discontinued).

${ }^{38}$ Ministry of Education China, "List of Institutions and Enrollment Plan for Undergraduate Clinical Medicine Programs Taught in English for International Students, 2016/2017," January 4, 2016, http://www.moe.gov.cn/srcsite/A20/moe_850/201601/ t20160120_228496.html.

${ }^{39}$ Aiyar, "Made in China Indian doctors," The Hindu, May 17, 2006, http://www.thehindu.com/todays-paper/tp-opinion/made-in-china-indian-doctors/article3134132.ece.

${ }^{40}$ CAFSA, "Statistics for international students in China 2015," April 18, 2016, http:// www.cafsa.org.cn/main/research/show-1662.html.

${ }^{41}$ Rita Sood, "Medical education in India," Medical Teacher 30, no. 6 (2008): 585-591.

${ }^{42}$ David Sancho, "Escaping India's culture of education: Migration desires among aspiring middle-class young men," Ethnography 18, no. 4 (2017): 3. 
who are academically as well as financially excluded from medical education at home are compelled to look overseas for alternatives. While previously medical schools located in certain eastern European countries (e.g., Ukraine, Russia, and Armenia) filled this gap, China has more recently emerged as the top player in this segment of the educational market. ${ }^{43}$ For example, during the 2011-2014 period, the largest group of candidates taking the Foreign Medical Graduates Exam (or FMGE-a mandatory licensing exam for Indian candidates trained in foreign countries other than the United States, United Kingdom, Canada, Australia, and New Zealand) was those educated in China. ${ }^{44}$

As earlier batches of graduates returned home to attempt the FMGE, however, their low passage rates began to be noticed by the public. In a Hindustan Times article titled ' $80 \%$ students flunk mandatory test after MBBS in China, Russia,' Vishav Bharti notes that between 2012 and 2014 , the exam pass rate for China-trained candidates was only $18.9 \%{ }^{45}$ As rising numbers of apparently under-prepared medical doctor candidates returned, there is now a general realization in India that 'foreign medical degrees are no longer fancy. ${ }^{36}$

These problematic outcomes dovetail with the first author's (Yang) observations during his ethnographic fieldwork at a provincial university in eastern China (to be referred to as 'CNU' in this chapter) where the international MBBS program was found to have serious quality issues with respect to admission screening, teaching and learning practices, student services, and so on. Yang's research on the Indian medical students in China was conducted between 2014 and 2016, adopting mainly an ethnographic approach. The fieldwork consisted of:

\footnotetext{
${ }^{43}$ Alya Mishra, "China has become preferred destination for medical education," September 9, 2012, http://www.universityworldnews.com/article.php?story=20120904100946519.

${ }^{44}$ Poulomi Banerjee, "Here's why foreign medical degrees are no longer fancy," Hindustan Times, November 23, 2015, http://www.hindustantimes.com/education/here-s-why-foreign-medical-degrees-are-no-longer-fancy/story-HpZtWmiCQFv877cfPqtXZO.html.

${ }^{45}$ Bharti, "80\% students flunk mandatory test after MBBS in China, Russia," Hindustan Times, 2015, http://www.hindustantimes.com/punjab/80-students-flunk-mandatory-testafter-mbbs-in-china-russia/story-MkWKHKKMdzihRNd2gRMKUN.html.

${ }^{46}$ Banerjee, "Here's why foreign medical degrees are no longer fancy."
} 
1. a week-long ethnographic observation and interaction with Indian MBBS students at CNU campus in March 2014;

2. a two-week trip to four Indian students' hometowns in the state of Tamil Nadu during June-July 2014;

3. a week-long visit to Kolkata and Bengaluru in early 2016 focusing on an India-based educational intermediary.

These intense ethnographic trips were further supplemented by Yang's continuous engagement with Indian student informants through social media.

\section{Pragmatism, Compromise, and Mediocrity: Realities of International Educational Mobility}

The case of Indian MBBS students in China materialized primarily as an outcome of the pragmatism of both the educational consumers and educational providers in attempting to achieve their respective objectives. For the Indian students, the objective is simply to obtain an MBBS degree at an affordable cost. For the Chinese universities, especially lower tier ones like CNU, it is to reap financial as well as prestige gains from having international students that they are otherwise not in a position to attract. As Yang's fieldwork revealed, however, the Indian students subsequently found the Chinese MBBS program falling short of their expectations, sometimes in significant and unsettling ways. Even so, they were generally willing to accept and acquiesce because this represented for them a 'second chance' that they must settle for. In other words, studying MBBS in China was a compromise that most Indian students have willingly made. Similarly, the Chinese institution also found its initial objective of achieving financial and reputational gains at least partially defeated, because not only did quite a number of Indian students struggle to pay tuition fee installments on time upon enrolling in China, their general lack of cultural capital (e.g., in areas of English proficiency, cosmopolitan outlook and competence, and academic ability) also added little prestige to CNU in the eyes of the university.

The Indian students' desires for an MBBS degree from China are primarily shaped locally in their home-country context as a tenuous strategy for achieving social mobility through education. Yang's informants-both the Indian students and their parents in the study-typically had very little prior knowledge about China and Chinese higher education institutes 
(HEIs), and did not in any significant way cite the imagined qualities of the host country and institution as reasons for their pursuit of this educational mobility. In fact, the only 'pull' factor consisted in the significantly lower tuition fees at the Chinese medical schools-equivalent to about a quarter to a third of what it costs in a private medical school in India. This finding contrasts notably with a few other accounts about international students in which active 'imaginative work' about the culture of the destination country/society and the features of its education system(s) featured prominently in students' narratives about studying abroad. ${ }^{47}$ This contrast shows that the socio-cultural construction of educational desires can be highly contingent contextually. While education has been theorized as a form of cultural capital that must be simultaneously institutionalized (as credentials/diplomas) and embodied, ${ }^{48}$ depending on context, social actors may emphasize predominantly only one aspect while bracketing the other. This seems to be the case with the Indian MBBS students in China, who primarily regard studying in China a second chance to obtain a credential that they are excluded from domestically; they seem to pay scant attention to the embodied as well as experiential aspects of their education in China.

Due to this local/domestic constructedness and orientation of the Indian students' rationality for pursuing MBBS in China, mobility in this case largely fails to act as a catalyst for value-added education. Educational mobility has often been touted for creating additional values to the multiplicity of actors involved in it, be it the countries, regions, cities, institutions, and most importantly, the people. ${ }^{49}$ For learners, especially, educational mobility is believed to be the key in enhancing one's cultural capital through opening access to advanced knowledge, inter-/crosscultural competencies, cosmopolitan perspectives, and so on. However, for the majority of the Indian MBBS students in Yang's study, few of these would seem true (although there inevitably are exceptions to the rule, which cannot be discussed here due to limit of space). As a telling example, most Indian MBBS students at CNU regarded learning the Chinese

\footnotetext{
${ }^{47}$ Suzanne E. Beech, "Why place matters: imaginative geography and international student mobility," Area 46, no. 2 (2014): 170-177; Fong, Paradise Redefined.

${ }^{48}$ Bourdieu, "The Forms of Capital."

${ }^{49}$ Francis L. Collins and Ho Kong Chong, "Globalising higher education and cities in Asia and the Pacific," Asia Pacific Viewpoint 55, no. 2 (2014): 127-131.; Francis L. Collins et al., "Mobility and desire: international students and Asian regionalism in aspirational Singapore," Discourse: Studies in the Cultural Politics of Education 35, no. 5 (2014): 661-676.
} 
language as extremely difficult and a burden. Language barriers, together with racially and socio-economically based prejudices and discriminations, led to the isolation of the Indian students in their host institution, as well as their general lack of interaction with the host society. Furthermore, in order to satisfy the learning needs of the Indian students, it is common for the Chinese universities to employ Indian-background lecturers to teach on the program. When Chinese lecturers taught according to their own China-based medical curriculum or syllabus, students typically reacted adversely instead of appreciating it as curricular diversity, citing the pragmatic consideration that the Chinese syllabus does not help them toward passing the India-based FMGE. In a similar vein, due to language and cultural barriers, Indian students are unable to benefit optimally from medical practicums conducted at hospitals in China.

These and various other observations reveal a palpable gap between the oft-claimed benefits of international educational mobility on the one hand and the realities as found in the experiences of the Indian MBBS students in China on the other. This case seems to show that, for academically and socio-economically not-so-privileged students pursuing educational mobility in non-elite institutions, a production of educational mediocrity ${ }^{50}$ may be a possible outcome.

\section{Case 2: Singaporean Students in Private Transnational Degree Providers}

\section{The Case of TNHE in Singapore's Private Institutes}

Transnationalization of HE driven by economic globalization gained momentum in the 1990s as part of the government's aim to transform Singapore into a global education hub. ${ }^{51}$ The government's search for 'global city' status through HE began in 1998 with the launch of the World Class Universities project to transform Singapore into 'Boston of the East'. A key strategy involved courting renowned American universities such as Wharton, MIT, Cornell, and Duke among others to establish satellite campuses and joint ventures in Singapore. The Global Schoolhouse initiative was introduced in 2002 as an explicit strategy to nurture HE as a service

\footnotetext{
${ }^{50}$ Le-Ha Phan, Transnational Education Crossing 'Asia' and 'the West.'

${ }^{51}$ Ravinder Sidhu, Kong Chong Ho, and Brenda S.A. Yeoh, "Emerging education hubs: the case of Singapore," Higher Education 61, no. 1 (2011): 23-40.
} 
sector for revenue growth vis-à-vis the fashioning of a 'virtuous circle,' whereby universities - especially research-intensive flagship institutes such as the National University of Singapore and the Nanyang Technological University-are perceived to generate talented citizens who would then create knowledge capital and networks that drive knowledge-based economy. ${ }^{52}$ In addition to transforming the domestic public-autonomous universities into global flagship centers of research and innovation excellence through various international partnership projects (such as Yale-NUS College of liberal arts and sciences, Duke-NUS medical school, and NTUStanford), the Global Schoolhouse initiative also encouraged the privatization of $\mathrm{HE}$ by attracting new players into the educational market. ${ }^{53}$

Private institutes in Singapore (and many parts of East and Southeast Asia) are not granted with degree-awarding powers but instead partner with overseas universities to offer programs that would lead to the conferment of a degree by the overseas 'home' university. The programs on offer include both part-time and full-time degree courses spanning across social sciences to business and marketing, offering a wide array of overseas credentials from reputable partner universities, such as University of London from the United Kingdom, University of Buffalo from the United States, and RMIT from Australia. These home universities also take advantage of these partnerships as part of their internationalizing strategies to grow their presence across the world and to capture a portion of the revenue afforded by this emerging transnational education industry. In forging these cross-border institutional linkages that facilitate networked circulation of educational models, knowledges, and policies, private HEIs serve as important individual sites in the global assemblage of Singapore's education hub formation. ${ }^{54}$ Much of this assemblage clearly thrives on the condition afforded by revolutionized technology, which has made possible new modes of collaboration, organization, and service provision in compressed time-space that is the current (neoliberal) imaginary.

The rapid expansion of a transnational private HE sector converged with the city-state's response to the increased tertiary participation rate produced by the mid-1980s school-leavers from the 'youth bulge' generation. This is

\footnotetext{
${ }^{52}$ Kris Olds, "Global Assemblage: Singapore, Foreign Universities, and the Construction of a 'Global Education Hub',' World Development 35, no. 6 (2007): 973.

${ }^{53}$ Peter Waring, "Singapore's global schoolhouse strategy: retreat or recalibration?," Studies in Higher Education 39, no. 5 (2013): 874-884.

${ }^{54}$ Olds, "Global Assemblage."
} 
compounded by a rising middle-class aspiration for higher qualifications and the continued impact of credential creep (i.e., the simultaneous inflation of minimum credentials required for a given job and devaluation of diplomas/ degrees). Due to recent public concerns about the lack of local university places for Singaporeans to pursue their degree education, the government convened a committee in 2012 to explore strategies for expanding the HE landscape culminating in a report for creating multiple university pathways. Private HE sector was construed in this report as having a 'role in complementing the public university sector, by injecting greater course diversity and supporting workforce development (emphasis added). ${ }^{55}$ Private HE was therefore framed within state policy discourse as demand-absorbing, providing opportunities to those who needed to upgrade workforce skills and knowledge, and expanding the educational service market.

According to the Council of Private Education, more than 100,000 Singaporeans pursue degree and diploma studies across approximately 71 private education institutes in Singapore. By 2012, there was already an estimated 47,500 Singaporeans enrolled in full-time and part-time undergraduate degree programs in the city's four largest private institutes. The majority are fresh A-level and diploma graduates who were unable (or did not try) to secure places in the more established and reputable publicautonomous flagship universities-namely the National University of Singapore, the Nanyang Technological University, and the Singapore Management University. Another group consists of young working adults in their 30s who wish to upgrade their existing credentials through 'topup' degree programs. Together, this sizeable student population has grown to match the number of Singaporeans enrolled into the local public universities, which was estimated to be just over 45,000 in the same year.

\section{Transnational Higher Education: Democratized and Borderless?}

The idea that private transnational education is a 'second chance' option to obtaining a degree began to emerge during the second author's (Cheng) ethnographic fieldwork conducted between 2012 and 2014. During this period, Cheng interacted with numerous domestic students in private HE,

\footnotetext{
${ }^{55}$ Ministry of Education Singapore, "Final Report of the Committee on University Education Pathways Beyond 2015," August 28, 2012, https://www.moe.gov.sg/docs/ default-source/document/ceup/2012/08/cuep-report-greater-diversity-more-opportunities.pdf ( site discontinued).
} 
out of which 35 interviews were held individually and in focus groups. Students spoke about private degree education as an alternative pathway to that of mainstream flagship universities, without which they would need to consider the more expensive route of pursuing a degree overseas. As such, the availability of overseas degree programs locally becomes a palpable option given they are more financially viable than living and studying abroad. While this dominant narrative reflects a form of students' practical reasoning, it is informed by private institutes' marketing discourses that employ the very same rhetoric of private degree education as offering young people a 'second go' at university education. Surveying various private institutes' websites revealed this language built into graduate and student 'testimonials' selected to promote their degree programs. In doing so, private education institutes participate in the appropriation and marketization of young people's aspirations, wherein students are framed as consumers and whose educational desires are increasingly co-opted into commercial agendas. ${ }^{56}$ As such, the 'second chance' discourse that helps frame local understandings of private degree education ${ }^{57}$ echoes more broadly held beliefs that TNHE offers the possibility of making university education borderless, contributing to widening participation, and by extension represent a more democratized moment of education and learning.

The vocabularies of borderless and democratization, however, serve to mask more complex and nuanced details of how disadvantage and hierarchies are produced through TNHE, even as it paves an additional route for credential-seeking youths. The analytic prism therefore needs to pay heed to how the 'actually existing' experiences of transnational education is constituted through reproduction of power relations and value hierarchies. As Waters and Leung argue based on their work on TNHE in Hong Kong, there is very little critical analysis on its complex spatialities-'how it can be conceivably both detached from the local education system and yet also at the same time profoundly implicated in localized processes of social reproduction. ${ }^{58}$

\footnotetext{
${ }^{56}$ Rajani Naidoo, Avi Shankar, and Ekant Veer, "The consumerist turn in higher education: Policy aspirations and outcomes," Journal of Marketing Management 27, no. 11-12 (2011): 1142-1162.

${ }^{57}$ Yi En Cheng, "Commentary: Is private higher education in Singapore a 'second chance' option?," September 17, 2017. http://www.channelnewsasia.com/news/singapore/ commentary-is-private-higher-education-in-singapore-a-second-9215636.

${ }^{58}$ Johanna Waters and Maggi W. H. Leung, "Domesticating transnational education: discourses of social value, self-worth and the institutionalisation of failure in 'meritocratic' Hong Kong," Transactions of the Institute of British Geographers, 42, no. 2 (2016): 235.
} 
Educational hierarchy in Singapore has long privileged 'Western' overseas universities, as reflected in the government's practice of sending the 'brightest' students abroad for university education in the Global North under prestigious scholarship schemes, followed by a more localized competition among the public universities. ${ }^{59}$ Private TNHE institutes, as the new kid on the block without the established resources and reputation relative to the domestic universities, are categorically pushed to the bottom rung of this hierarchy. Domestic students enrolled into private institutes are structurally constituted as 'educated non-elites' in the state's vision of Singapore as an epicenter of knowledge and talent. ${ }^{60}$ Even though many of them are considered relatively privileged enough to be able to pursue university education, as opposed to the least advantaged youths in vocational and technical institutes ${ }^{61}$ or those who have no financial means to pursue $\mathrm{HE}$, private degree students often face uncertainty in job prospects and do not have access to a wide variety of employment opportunities unlike their counterparts studying in domestic public-autonomous universities. This is largely due to the lack of faith in TNHE programs and degree credentials by employers and hirers that can be attributed to multiple factors, including stereotypical views about the quality of students and programs. Currently, $42 \%$ of graduates of private TNHE were unable to secure full-time jobs within six months of completing their studies, which is a striking contrast to an $83 \%$ successful full-time job rate among the public university students. ${ }^{62}$ Two key points about the challenges faced by private TNHE students in Singapore can be made that connect to localized social reproduction.

First, even though Western overseas universities and their credentials are much sought after by employers in Singapore, they do not remain as such in the context of private TNHE. Instead, private TNHE-awarded degrees undergo a process of value erosion as they cross geographical boundaries

\footnotetext{
${ }^{59}$ Rebecca Ye and Erik Nylander, "The transnational track: state sponsorship and Singapore's Oxbridge elite," British Journal of Sociology of Education 36, no. 1 (2015): $11-33$.

${ }^{60}$ Yi En Cheng, "Educated non-elites' pathways to cosmopolitanism: the case of private degree students in Singapore," Social \& Cultural Geography 19, no. 2 (2018): 151-170. https://doi.org/10.1080/14649365.2016.1266026.

${ }^{61}$ Terence Chong, "Vocational education in Singapore: meritocracy and hidden narratives," Discourse: Studies in the Cultural Politics of Education 35, no. 5 (2014): 637-648.

${ }^{62}$ Sandra Davie, "Private school graduates find it harder to land jobs: Poll," The Straits Times, September 24, 2016, http://www.straitstimes.com/singapore/education/ private-school-grads-find-it-harder-to-land-jobs-poll.
} 
and get reinterpreted in the local context of existing HE hierarchies vis-àvis a politics of value recognition tied to student worth and institutional reputation. This cross-border erosion of (Western) credential value poses a challenge to the notion of TNHE as a form of borderless education that can uproot itself from geographically embedded forces.

The second point relates to how TNHE has been postulated to have democratizing impact on participation in HE. The case of Singapore has indeed demonstrated the possibility of widening university participation for a broader range of young people, and which serves as a discourse that appeals to the popular imagination, including the students' own perceptions of private TNHE. Nevertheless, it is also revealed through research that more complex intricacies of power relations operating within private institutes continue to reproduce (dis)advantage. For instance, even within a single institute some university programs are perceived as better than others. Generally, American degree programs are perceived by students as of a higher class than the Australian counterparts. But those who wish to enroll into the American programs would have to pay a higher tuition fee as compared to Australian universities. In terms of access to opportunities to partake in overseas study and work placements that might support future employability, there is also evidence that some working-class students could not afford to pay for additional expenses needed to enter such programs. As such, while TNHE offers the possibility of international education experience with respect to their foreign curricular programs, not every student has equal access to tangible forms of international learning experiences and especially for socio-economically constrained individuals. These exclusions on the ground serve as a caution to viewing TNHE as any more democratic than earlier forms of educational arrangements.

\section{Discussion AND Conclusion}

While we could have offered a discussion of how HE may be impacted by and can in turn respond to 4IR from a functionalist angle, evidently this is not the approach we have taken in this chapter. Instead, leveraging on our respective studies in emerging student mobilities and transnational private $\mathrm{HE}$ in Asia, we have attempted to reflect indirectly on claims tied to 4IR as a technologically enabled and driven force that would disrupt HE learning and training. In the process, we have pondered the roles of student mobility, transnationalization, economic/social/cultural capitals, social reproduction-and the complex cross-border interplay of these factorsin animating today's global landscape of HE. 
Transnational mobilities and connectivities in HE have no doubt become deeper and more extensive as the result of the 3IR-driven globalization of the preceding era. With the onset of the 4IR, these processes are likely to further accelerate and intensify. This notwithstanding, our research suggests that the patterns of educational mobilities and transnational linkages are highly uneven, and remain powerfully shaped by hegemonic global structures and hierarchies around knowledge authority, institutional prestige, and country reputations. Our findings show that today's HE institutions adopt 'globalization' or 'internationalization'often in ways that reflect dominant technofetishized impulses-as strategies to boost student enrollment, whereas students often use their participation in educational mobilities and transnationalism as alternative routes to overcome locally based barriers to access educational pathways and labor markets. Thus, we contend that, while examining the globalizing aspects of $\mathrm{HE}$ and participation that are often associated with globalization and are projected to intensify in the age of 4IR, we must not lose sight of the locally embedded logics and rationales underpinning institutions' and individuals' articulations and experiences of HE.

More broadly, with the critical and culturalist analytical perspective we adopt, our hope through this chapter is to open up a more critical conversation about the current state and future direction of scholarship on 4IR and HE. Existing discourses on 4IR remain very much dominated by the elite industrial and academic voices that coined the concept in the first place. ${ }^{63}$ Characterized by a strong technocratic/technophilic impulse and futuristic orientation, such discourses address primarily the policymakers and the elites, but elide the 'on the ground' experiences and subjectivities of the more disadvantaged and marginalized. Hence, for instance, in the WEF's recent report The Future of Jobs: Employment, Skills and Workforce Strategy for the Fourth Industrial Revolution, there are many a prediction and pronouncement about the 'hot' skills of the future, which all seem to us to be largely out of touch with the ways in which socio-culturally and geographically embedded actors are engaging with $\mathrm{HE}$ as means of realizing locally defined social aspirations and desires. ${ }^{64}$ In a sense, our chapter aspires to be a corrective to prevailing 4IR discourses which fail to

${ }^{63}$ Schwab, The First Industrial Revolution.

${ }^{64}$ World Economic Forum, "The Future of Jobs: Employment, Skills and Workforce Strategy for the Fourth Industrial Revolution," January 2016, http://www3.weforum.org/ docs/WEF_Future_of_Jobs.pdf. 
challenge the continued hegemony of the business world and capitalist economy impacting upon HE alongside the unevenness, hierarchies, and inequalities that are reproduced in the process. We argue that paying attention to these issues is crucial if we wish to take seriously and critically the complex relationships between 4IR and higher education.

\section{BIBLIOGRAPHY}

Aiyar, Pallivi. "Made in China Indian doctors." The Hindu, May 17, 2006. http:// www.thehindu.com/todays-paper/tp-opinion/made-in-china-indian-doctors/ article3134132.ece.

Altbach, Philip G. "Higher Education and the WTO: Globalization Run Amok." International Higher Education 23, (2001): 2-4.

Agarwal, Anant. "MOOCs and the Global Democratization of Higher Education." June 24, 2016. https://evolllution.com/attracting-students/accessibility/ moocs-and-the-global-democratization-of-higher-education/.

Baas, Michiel. Imagined Mobility: Migration and Transnationalism among Indian Students in Australia. New York: Anthem Press, 2010.

Baláž, Vladimír, and Allan M. Williams. "Been there, done that': international student migration and human capital transfers from the UK to Slovakia." Population, Space and Place 10, no. 3 (2004): 217-237.

Banerjee, Poulomi. "Here's why foreign medical degrees are no longer fancy." Hindustan Times, November 23, 2015. http://www.hindustantimes.com/ education/here-s-why-foreign-medical-degrees-are-no-longer-fancy/storyHpZtWmiCQFv877cfPqtXZO.html.

Beech, Suzanne E. "Why place matters: imaginative geography and international student mobility." Area 46, no. 2 (2014): 170-177.

Bharti, Vishav. "80\% students flunk mandatory test after MBBS in China, Russia." Hindustan Times, 2015. http://www.hindustantimes.com/punjab/80-students-flunk-mandatory-test-after-mbbs-in-china-russia/story-MkWKHKKMdzihRNd2gRMKUN.html.

Bourdieu, Pierre. "The Forms of Capital." In Handbook of Theory and Research for the Sociology of Education, edited by John G. Richardson, 241-260. London: Greenwood Press, 1986.

Brooks, Rachel, and Johanna Waters. "A Second Chance at 'Success': UK Students and Global Circuits of Higher Education." Sociology 43, no. 6 (2009): $1085-1102$.

CAFSA. "Statistics for international students in China 2015." April 18, 2016. http://www.cafsa.org.cn/main/research/show-1662.html.

Chan, Sheng-Ju. "Shifting Patterns of Student Mobility in Asia." Higher Education Policy 25, no. 2 (2012): 207-224. 
Cheng, Yi En. “Educated non-elites' pathways to cosmopolitanism: the case of private degree students in Singapore." Social \& Cultural Geography 19, no. 2 (2018): 151-170. https://doi.org/10.1080/14649365.2016.1266026.

—. "Commentary: Is private higher education in Singapore a 'second chance' option?" September 17, 2017. http://www.channelnewsasia.com/news/ singapore/commentary-is-private-higher-education-in-singapore-asecond-9215636.

Chong, Terence. "Vocational education in Singapore: meritocracy and hidden narratives." Discourse: Studies in the Cultural Politics of Education 35, no. 5 (2014): 637-648.

Collins, Francis L. "Regional Pathways: Transnational Imaginaries, Infrastructures and Implications of Student Mobility within Asia." Asian and Pacific Migration Journal 22, no. 4 (2013): 475-500.

Collins, Francis L., and Ho Kong Chong. "Globalising higher education and cities in Asia and the Pacific." Asia Pacific Viewpoint 55, no. 2 (2014): 127-131.

Collins, Francis L., Ravinder Sidhu, Nick Lewis, and Brenda S.A. Yeoh. "Mobility and desire: international students and Asian regionalism in aspirational Singapore." Discourse: Studies in the Cultural Politics of Education 35, no. 5 (2014): 661-676.

Collins, Randall. "Functional and Conflict Theories of Educational Stratification." American Sociological Review, 36, no. 6 (1971): 1002-1019.

Cunningham, Stuart, Yoni Ryan, Lawrence Stedman, Suellen Tapsall, Kerry Bagdon, Terry Flew, and Peter Coldrake. The Business of Borderless Education. Canberra: DETYA, 2000.

Davie, Sandra. "Private school graduates find it harder to land jobs: Poll." The Straits Times, September 24, 2016. http://www.straitstimes.com/singapore/ education/private-school-grads-find-it-harder-to-land-jobs-poll.

Fang, Wenhong. "The development of transnational higher education in China: A comparative study of research universities and teaching universities." Journal of Studies in International Education 16, no. 1 (2012): 5-23.

Findlay, Allan. M., Russell King, Fiona M. Smith, Alistar Geddes, and Ronald Skeldon. "World class? An investigation of globalisation, difference and international student mobility." Transactions of the Institute of British Geographers, 37, no. 1 (2012): 118-131.

Fong, Vanessa L. Paradise Redefined: Transnational Chinese Students and the Quest for Flexible Citizenship in the Developed World. Stanford: Stanford University Press, 2011.

Huang, Futao. "Internationalization of higher education in the developing and emerging countries: A focus on transnational higher education in Asia." Journal of Studies in International Education 11, no. 3-4 (2007): 421-432. 
ICEF Monitor. "The state of international student mobility in 2015." November 5, 2015. http://monitor.icef.com/2015/11/the-state-of-international-studentmobility-in-2015/.

King, Russell, and Enric Ruiz-Gelices. "International student migration and the European 'Year Abroad': effects on European identity and subsequent migration behaviour." International Journal of Population Geography 9, no. 3 (2003): 229-252.

King, Russell, Findlay, Allan M., Jill Ahrens, and Mairead Dunne. "Reproducing advantage: the perspective of English school leavers on studying abroad." Globalisation, Societies and Education 9, no. 2 (2011): 161-181.

Koch, Natalie. "The shifting geopolitics of higher education: inter/nationalizing elite universities in Kazakhstan, Saudi Arabia and beyond." Geoforum 56, (2014): 46-54.

Kuroda, Chiharu. "The New Sphere of International Student Education in Chinese Higher Education: A Focus on English-Medium Degree Programs." Journal of Studies in International Education 18, no. 5 (2014): 445-462.

Mazzarol, Tim W., Geoffery N. Soutar, and Michael S. Y. Seng. "The third wave: Future trends in international education." The International Journal of Education Management 17, no. 3 (2003): 90-99.

Medical Council of India. "List of China Colleges." 2015. http://www.mciindia. org/MediaRoom/ListofChinaColleges.aspx (site discontinued).

Ministry of Education China. "List of Institutions and Enrollment Plan for Undergraduate Clinical Medicine Programs Taught in English for International Students, 2016/2017." January 4, 2016. http://www.moe.gov.cn/srcsite/ A20/moe_850/201601/t20160120_228496.html.

Ministry of Education Singapore. "Final Report of the Committee on University Education Pathways Beyond 2015." August 28, 2012. https://www.moe.gov. $\mathrm{sg} /$ docs/default-source/document/ceup/2012/08/cuep-report-greaterdiversity-more-opportunities.pdf (site discontinued).

Mishra, Alya. "China has become preferred destination for medical education." September 9, 2012. http://www.universityworldnews.com/article. php?story $=20120904100946519$.

Naidoo, Rajani, Avi Shankar, and Ekant Veer. "The consumerist turn in higher education: Policy aspirations and outcomes." Journal of Marketing Management 27, no. 11-12 (2011): 1142-1162.

OECD. "Education Indicators in Focus - 2013/05 (July)." 2013. http://www. oecd.org/edu/skills-beyond-school/EDIF\%202013--N\%C2\%B014\%20 $\% 28$ eng\%29-Final.pdf.

Olds, Kris. "Global Assemblage: Singapore, Foreign Universities, and the Construction of a "Global Education Hub"." World Development 35, no. 6 (2007): 959-975. 
Phan, Le-Ha. Transnational Education Crossing 'Asia' and 'the West': Adjusted desire, transformative mediocrity and neo-colonial disguise. London: Routledge, 2017.

PRC State Council. "More Chinese students return from overseas in 2016." March 1, 2017. http://english.gov.cn/state_council/ministries/2017/03/01/content_281475581664446.htm.

Robertson, Shanthi. Transnational Student-Migrants and the State: The EducationMigration Nexus. London: Palgrave Macmillan, 2013.

Robins, Kevin, and Frank Webster. The Virtual University? Knowledge, Markets, and Management. Oxford: Oxford University Press, 2002.

Rossman, Parker. The Emerging Worldwide Electronic University: Information Age and Higher Education. Westport: Greenwood Press, 1992.

Sancho, David. "Escaping India's culture of education: Migration desires among aspiring middle-class young men." Ethnography 18, no. 4 (2017): 1-20.

Schwab, Klaus. "The Fourth Industrial Revolution: what it means, how to respond." January 14, 2016. https://www.weforum.org/agenda/2016/01/ the-fourth-industrial-revolution-what-it-means-and-how-to-respond/.

- The Fourth Industrial Revolution. New York: Crown Publishing Group, 2017.

Sharma, Yojana. "Universities can help overcome economic nationalism." November 23, 2017. http://www.universityworldnews.com/article.php? story=20171123200015564.

Sidhu, Ravinder, Kong Chong Ho, and Brenda S.A. Yeoh. "Emerging education hubs: the case of Singapore." Higher Education 61, no. 1 (2011): 23-40.

Sood, Rita. "Medical education in India." Medical Teacher 30, no. 6 (2008): $585-591$.

UNESCO. "The International Mobility of Students in Asia and the Pacific." 2013. http://unesdoc.unesco.org/images/0022/002262/226219E.pdf.

_. "Global Flow of Tertiary-Level Students." 2016. http://www.uis.unesco. org/Education/Pages/international-student-flow-viz.aspx (site discontinued).

UNESCO-CEPES. Code of Good Practice in the Provision of Transnational Education. Bucharest: UNESCO/Council of Europe, 2000.

Waring, Peter. "Singapore's global schoolhouse strategy: retreat or recalibration?" Studies in Higher Education 39, no. 5 (2013): 874-884.

Waters, Johanna. "Geographies of cultural capital: education, international migration and family strategies between Hong Kong and Canada." Transactions Institute of British Geographers 31, no. 2 (2006): 179-192.

- Education, Migration, and Cultural Capital in the Chinese Diaspora. Transnational Students between Hong Kong and Canada. New York: Cambria Press, 2008. 
—. "Geographies of International Education: Mobilities and the Reproduction of Social (Dis)advantage." Geography Compass 6, no. 3 (2012): 123-136.

Waters, Johanna, and Maggi W. H. Leung. "Domesticating transnational education: discourses of social value, self-worth and the institutionalisation of failure in "meritocratic" Hong Kong." Transactions of the Institute of British Geographers, 42, no. 2 (2016): 233-245.

World Economic Forum. "The Future of Jobs: Employment, Skills and Workforce Strategy for the Fourth Industrial Revolution.” January 2016. http://www3. weforum.org/docs/WEF_Future_of_Jobs.pdf.

Yang, Peidong. "Compromise and complicity in international student mobility: the ethnographic case of Indian medical students at a Chinese university." Discourse: Studies in the Cultural Politics of Education, online first (2018): 1-15.

Yang, Rui. "Globalisation and higher education development: a critical analysis." International Review of Education, 49 no. 3-4 (2003): 269-291.

Ye, Rebecca, and Erik Nylander. "The transnational track: state sponsorship and Singapore's Oxbridge elite." British Journal of Sociology of Education 36, no. 1 (2015): 11-33.

Ziguras, Christopher, and Grant McBurnie. "International Student Mobility in the Asia-Pacific: From Globalization to Regional Integration?" In Higher Education in the Asia-Pacific, edited by Simon Marginson, Sarjit Kaur, and Erlenawati Sawir, 123-140. Netherlands: Springer, 2011.

Open Access This chapter is licensed under the terms of the Creative Commons Attribution 4.0 International License (http://creativecommons.org/licenses/ by $/ 4.0 /)$, which permits use, sharing, adaptation, distribution and reproduction in any medium or format, as long as you give appropriate credit to the original author(s) and the source, provide a link to the Creative Commons license and indicate if changes were made.

The images or other third party material in this chapter are included in the chapter's Creative Commons license, unless indicated otherwise in a credit line to the material. If material is not included in the chapter's Creative Commons license and your intended use is not permitted by statutory regulation or exceeds the permitted use, you will need to obtain permission directly from the copyright holder.

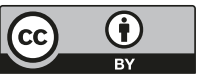

